\title{
Provokativ offentlig filosofi
}

\section{Aksel Braanen Sterri}

Universitetet i Oslo, Institutt for filosofi, ide- og kunsthistorie og klassiske språk, akselbst@ifikk.uio.no

DOI: http://dx.doi.org/10.5324/eip.v12i2.2539

(cc) BY This is an open access article distributed under the terms of the Creative Commons Attribution 4.0 International License, which permits unrestricted use, distribution, and reproduction in any medium, provided the original author and source are credited.

En uttalelse om at personer med Downs syndrom ikke kan leve fullverdige liv, satte i gang en stor og opphetet debatt $i$ den norske offentligheten i 2017. Denne ga opphav til en mer overordnet debatt om hva akademikere bør og ikke bør si i offentligheten. En viss form for offentlig filosofi, det jeg vil kalle provokativ offentlig filosofi, er blitt utpekt som synder. I denne artikkelen vil jeg, med utgangspunkt $i$ debatten om fullverdige liv, forsvare provokativ offentlig filosofi mot både epistemiske og etiske innvendinger.

Nøkkelord: Filosofisk argumentasjon, offentlig debatt, offentlig filosofi, sorteringssamfunnet, Downs syndrom, fullverdige liv, eugenikk

English summary: Provocative Public Philosophy

In 2017, I argued that people with Down syndrome cannot live full lives. This sparked a heated debated in the Norwegian public sphere. This gave rise to a debate over what academics should and should not say in public. A certain form of public philosophy, what I will call provocative public philosophy, was criticized for being harmful, imperialistic, for eroding trust in philosophers, and for creating too much noise. In this article I will, in light of the Down syndrome debate, defend provocative public philosophy against these allegations.

Keywords: Philosophical argumentation, public debate, public philosophy, Down syndrome, eugenics

\section{Innledning}

Kan personer med Downs syndrom leve fullverdige liv? I et intervju med Minerva hevdet jeg at de ikke kunne det (Sørvig 2017). Intervjuet, som ble publisert dagen etter at jeg hadde begynt som stipendiat i filosofi ved Universitetet i Oslo, sparket i gang en sjeldent opphetet offentlig debatt som varte i flere måneder. Konteksten for uttalelsen var etikken knyttet til selektiv abort, men jeg vil likevel omtale debatten som "debatten om fullverdige liv".

Debatten ble svært betent. Kristin Bliksrud Aavitsland og Eivor Andersen Oftestad (2017) spurte om jeg ville ha drept tusenvis av funksjonshemmede hvis jeg "var blant de velmenende legene på Sonnenstein", hvor Hitlers eutanasi- 
program fant sted. Lars Egeland (2017) sammenlignet mine ytringer med de som "endte i overgrep hvor nazistenes drap på psykisk utviklingshemmede var generalprøven på holocaust”. Bjørnar Laabak, statssekretær fra Frp, mente mennesker med holdninger som mine ikke burde tilbys stipendiatstillinger (Moen 2017), og flere professorer ved Universitetet i Oslo ba rektor om å ta offentlig avstand fra verdigrunnlaget som lå bak ytringene, noe han imidlertid nektet å gjøre (Lindqvist 2017).

Jeg tror på verdien av det jeg i denne teksten vil kalle provokativ offentligfilosofi. Dette består i å gå inn i betente temaer, utfordre konsensus og følge argumentene til deres logiske konsekvens, uavhengig av om ideene eller konklusjonene oppleves ubehagelige eller har en mørk fortid. Debatten om fullverdige liv framstår imidlertid som et klart eksempel på at provokativ offentlig filosofi kan spore av og oppleves støtende. Vi bør derfor ta denne type offentlig filosofering opp til debatt, og vurdere, mer generelt, hvordan vi bør drive offentlig filosofi.

Jeg er ikke alene om å tenke i disse baner. Inga Bostad (2017) brukte debatten om fullverdige liv som springbrett for en debatt om de kommunikative normene akademikere bør holde seg med. Hun antydet at enkelte synspunkter burde forbeholdes fagseminarene. Hofmann og Carson (2018) ser mitt bidrag spesielt, og en konsekvensialistisk inspirert offentlig filosofi mer generelt, som en moderne form for sofisteri, som kan skape mer forvirring enn den oppklarer, og dermed skade filosofiens rykte. Slik jeg forstår dem, kritiserer begge provokativ offentlig filosofi.

Jeg tror debatten om fullverdige liv er en passende utfordring for min posisjon. Debatten om fullverdige liv var til tider sårende, skapte mye støy og var, til dels grunnet mine egne bidrag, ikke så klar som den burde vært. Den er derfor et least likely case for påstanden om at vi bør bedrive provokativ offentlig filosofi. I den grad vi kan bruke enkelttilfeller for å styrke eller svekke generelle påstander, bør vi velge våre kasus med omhu. Da Robert Michel (1915) studerte oligarkiets jernlov, teorien om at alle organisasjoner vil utvikle seg til å bli styrt fra toppen, valgte han å ta for seg det tyske sosialdemokratiske partiet. Med dets egalitære idealer var partiet et least likely case for teorien; hvis også denne organisasjonen utviklet et fåmannsvelde, var det grunn til å tro at det ville skje hvor som helst. Det samme vil jeg si gjelder i dette tilfellet. Hvis provokativ offentlig filosofi fortsatt framstår som et appellerende alternativ etter møte med denne debatten, så bør vi være styrket $\mathrm{i}$ troen på den.

Jeg vil imidlertid ikke begrense meg til debatten om fullverdige liv. Jeg vil først skissere opp hva jeg mener med en provokativ offentlig filosofi, kontrastere den med en varsom offentlig filosofi, og si noe om hvorfor vi bør drive med offentlig filosofi. Jeg vil så gi en gjennomgang av debatten om fullverdige liv, hvor jeg imøtegår en del av de substansielle innvendingene som kom i løpet av debatten. Deretter vil jeg analysere hvorvidt mitt eget bidrag levde opp til kriteriene for provokativ offentlig filosofi. Jeg vil deretter ta for meg en rekke innvendinger mot provokativ offentlig filosofi, inspirert av debatten om fullverdige liv. Jeg håper å vise at provokativ offentlig filosofi, på tross av svakhetene ved debatten om fullverdige liv, er en modell til etterfølgelse. 


\section{To offentlige filosofier}

Jeg vil foreslå at målet med offentlig filosofi er det følgende: Å gi folk filosofisk innsikt ved å delta i det offentlige ordskiftet med mål om å gjøre dem bedre stilt til å besvare problemstillinger som er viktige for dem. Ulike filosofer har imidlertid ulike innfallsvinkler til hvordan dette målet best oppnås.

Provokativ offentlig filosofi er i korte trekk utfordrende, normativ, aktivistisk og eksplisitt. Målet er å endre verden ved å utfordre folk til å tenke nytt på ting de tar for gitt. Provokativ offentlig filosofi søker å oppnå det ved å utfordre etablerte oppfatninger, og komme med klare konklusjoner, selv om disse er ubehagelige og går på tvers av enkelte av våre intuisjoner. Målet er imidlertid $i k k e$ provokasjon; at en gitt provokativ filosofi provoserer, bør snarere betraktes som en akseptert, forventet konsekvens av denne måten å drive offentlig filosofi på.

Varsom offentlig filosofi har en annen inngang til hvordan bedrive offentlig filosofi. Varsom filosofi består gjerne av å vise fram at en sak kan belyses fra flere sider, og at fornuftige mennesker kan være uenige. Slik sett er den mer beskrivende og mindre normativ. Varsomme filosofer vil også i mange tilfeller begrense seg til å presentere faglig konsensus, og holde sine egne "kjepphester" til fagdebattene. Varsomme filosofer vil også i mange tilfeller sette seg fore å forsvare allmennmoralen. Slik sett er den varsomme filosofien mindre aktivistisk.

Siden målet ikke nødvendigvis er å konkludere med hva som er riktig i en gitt sak, kan varsomme filosofer i større grad tillate seg å fokusere på ett aspekt ved et komplisert sakskompleks og vise at vi ikke tenker tilstrekkelig godt om dette. Slik sett er den varsomme offentlige filosofien mer problematiserende.

Siden provokativ offentlig filosofi forsøker å komme med klare konklusjoner om hva vi bør gjøre, er denne veien lukket. Provokativ offentlig filosofi må derfor bedrive helhetlige vurderinger hvor alle relevante forhold tas med i betraktningen og vurderes opp mot hverandre; for bare slik kan vi konkludere. Dette er også med på å gjøre provokativ offentlig filosofi provoserende. På grunn av kommunikasjonsmediets plassbegrensninger og filosofens skylapper og implisitte verdivurderinger vil mange forsøk på provokativ offentlig filosofi gi inntrykk av å foreta helhetlige vurderinger, men likevel utelate en rekke potensielt relevante hensyn. I debatten om fullverdige liv kritiserer Hofmann og Carson (2018), Lindstad (2017) og Andresen (2017) undertegnede for ikke i tilstrekkelig grad å være eksplisitt på alle verdivurderingene og for ikke å behandle alle relevante motargumenter.

Eksempler på provokativ filosofi er Julian Savulescus forsvar for at kvinner bør kunne velge barnets kjønn, og for at kvinner bør velge barn som har de beste forutsetninger for å leve gode liv (Savulescu 1999, 2001), og Peter Singer (1979) og Jeff McMahans (2002) forsvar for at spedbarnsdrap i enkelte tilfeller er rettferdiggjort, samt deres felles forsvar for at en eldre kvinnelig professors seksuelle samkvem med en kognitivt svært begrenset mann ikke bør regnes som voldtekt (McMahan og Singer 2017). Også andre moralfilosofer, som Janet Radcliffe Richards og David Benatar, er kjent for provokativ offentlig filosofering. Selv om det er enklest å forestille seg eksempler på offentlig moralfilosofi, mener jeg ikke å begrense diskusjonen av offentlig filosofi til det domenet. Eksempler utenfor moralfilosofien kan være Harry Frankfurts (2005) analyse av bullshit og Katie Mannes (2017) analyse av misogynisme. 
Et godt stykke varsom filosofi om selektiv abort er Berge Solbergs artikkel "Frykten for et samfunn uten Downs syndrom" (2008). Her forklarer Solberg godt hvorfor fosterdiagnostikk og selektiv abort er spesielt følsomt i tilfellet Downs syndrom. Det begrunner han med at denne tilstanden henger så tett sammen med personens identitet. Artikkelen bidrar til å rydde i debatten, uten at Solberg selv tar stilling til hva vi bør gjøre. Som han konkluderer med: "Formålet her har kun vært å påvise at det er reelle grunner for å drøfte fosterdiagnostikk opp mot ideen om et inkluderende samfunn og identitetsbeskrivelsene et slikt samfunn gir rom for." (Solberg 2008: 49) Denne forsiktigheten speiler også Solbergs offentlige filosofi. Et annet eksempel på varsom filosofi finner vi hos Lars Fredrik Svendsen, som blant annet har utforsket filosofiske aspekter knyttet til arbeid, frihet og kjedsomhet. Denne formen for offentlig filosofi kan gi oss nye perspektiver og få oss til å tenke annerledes, men det er i mindre grad filosofen selv som forteller oss hvilke lærdommer vi bør trekke. De trekker vi selv.

Provokativ og varsom offentlig filosofi er idealtyper. I praksis vil filosofers bidrag bevege seg mellom disse. For eksempel kan Ketil Slagstad og Bjørn Hofmanns (2017) Morgenbladet-artikkel om den fosterdiagnostiske blodprøven NIPT være et eksempel på en hybrid. De utforsker ulike sider ved temaet og stiller en rekke mer eller mindre retoriske spørsmål som ikke besvares. Slik sett kvalifiserer bidraget som varsom offentlig filosofi. Selv om konklusjonene er kvalifiserte og til tider tildekket som retoriske spørsmål, er de imidlertid også klart normative og aktivistiske. Slik sett nærmer de seg provokativ offentlig filosofi. Det samme gjelder Morten Magelssens deltakelse i debatten om fullverdige liv (Sollien 2017a), hvor han er tydelig aktivistisk og normativ, men likevel er varsom i den forstand at han framhever enkelte aspekter av saken, og i mindre grad løfter fram sine mest kontroversielle syn, som et svært restriktivt syn på abort (Magelssen 2013).

Både provokativ og varsom offentlig filosofi er nye begreper, så det kan være nyttig å kontrastere dem med en mer kjent offentlig filosofi, nemlig den sokratiske. Den sokratiske filosofien tar form som en dialog hvor en forsøker å utfordre våre etablerte sannheter, gjerne for å avsløre at vi ikke vet så mye som vi tror vi vet. Provokativ og sokratisk offentlig filosofi deler målet om å utfordre etablerte tenkemåter for å få oss til å tenke og forhåpentligvis handle bedre. ${ }^{1}$ Sokrates' filosofi ble også oppfattet som uhøflig, ubehagelig, provoserende og til tider hensynsløs, noe provokativ offentlig filosofi også kan bli. Den sokratiske metoden skiller seg fra provokativ offentlig filosofi ved at det er, i likhet med den varsomme offentlige filosofien, mottakeren selv som får trekke konklusjonene. Det kan selvfølgelig innvendes at de som tok eller tar i bruk den sokratiske metoden, ofte vet hvor de vil hen med sine utspørringer, men metoden går likevel ut på å få samtalepartneren til selv å innse sine feil og korrigere dem, og ikke presentere dem for sannheten, slik utfordreren ser den.

Den dialogiske formen på den sokratiske filosofien er imidlertid begrunnet i et egalitært ideal jeg mener provokativ offentlig filosofi deler. Provokativ offentlig filosofi handler ikke om å tre ned fra elfenbenstårnet og fortelle allmuen hva filosofer er enige eller uenige om. Filosofer som tar i bruk provokativ offentlig filosofi, tar for seg spørsmål som er relevante i folks hverdag og politiske liv, og forsøker å argumentere så godt de kan for én posisjon. Men siden hver og en av oss er feilbarlige, er dette innspillet bare starten på en dialog med alle dem som ønsker 
å melde seg på. Provokativ offentlig filosofi er dermed, i likhet med den sokratiske filosofien, egalitær og dialogisk, selv om den altså tar en mer konkluderende form. ${ }^{2}$ Jeg vil returnere til disse idealene i artikkelens siste del, hvor jeg forsvarer provokativ offentlig filosofi mot en rekke innvendinger. ${ }^{3}$

Den offentlige filosofien har en mulig parallell i akademisk filosofi. Provoserende og varsom offentlig filosofi kan sies å speile skillet i den akademiske filosofien mellom revisjonistene, som til tider forsvarer radikale avvik fra allmennmoralen, og de som forsøker å gi en koherent og best mulig forklaring av våre ulike moralske oppfatninger som tilsynelatende kan virke motstridende. Det er mange konsekvensialister blant revisjonistene, men det er langt fra fullstendig overlapp. Eksempler på revisjonistiske filosofer som ikke er konsekvensialister, er Jeff McMahan, Jason Brennan, Espen Gamlund og tidlige arbeider av Julian Savulescu.

\section{Debatten om fullverdige liv}

Et av temaene i intervjuet med Minerva som satte i gang debatten om fullverdige liv, var de eventuelle etiske grensene for hvilke fostre kvinner bør kunne velge bort. I den anledning uttalte jeg at "[d]e som har Downs vil aldri kunne leve fullverdige liv, uansett hvor mye vi som samfunn legger til rette for det." (Sørvig 2017)

Med fullverdige liv mente jeg utelukkende å karakterisere hvor gode livene til personer med Downs syndrom er, og ikke si noe om menneskeverdet til mennesker med Downs syndrom. Med andre ord, jeg forsøkte å si noe om livskvalitet, ikke om moralsk status. ${ }^{4}$ Som jeg beskrev det i Morgenbladet: "Personer med Downs syndrom har kapasitet til å leve lykkelig og de kan ha en større evne til å kjenne pur glede enn andre (Skotko; Levine og Goldstein 2011), men de har også større risiko for å oppleve depresjon og mentale lidelser (Foley mfl. 2015), og de lever liv med mange flere sykdommer og utfordringer (Thomas mfl 2010; Roizen 2010; Haddad, Bourke, Wong og Leonard 2018). Siden de er avhengige av betydelig grad av tilrettelegging, vil også mange leve et ensomt og institusjonalisert liv, med mindre mulighet til å søke gleder og unngå lidelse enn det andre kan.” (Bertoli 2011; Oates, Bebbington, Bourke, Girdler og Leonard 2011; Haddad mfl. 2018) (Sterri 2017a, referansene var ikke med i opprinnelig tekst.) ${ }^{5}$ Jeg påpekte også at personer med Downs syndrom, på grunn av sin psykiske utviklingshemming, er begrenset fra å kunne ta del i en rekke goder vi gjerne anser som sentrale i et godt menneskeliv, som for eksempel en aktiv deltakelse i samfunnslivet.

En kan imidlertid spørre, som Sigurd Lindstad (2017), hvorfor ulik livskvalitet er relevant for hvorvidt selektiv abort bør tillates. For fosteret som har fått påvist Downs syndrom, er det ingen fordel om det blir abortert bort og eventuelt erstattet av et annet barn i stedet. Det vil bare være en fordel hvis livet ikke ville være verdt å leve, og det er en lite plausibel påstand (se bl.a. Sterri 2017c).

For å besvare hvorfor livskvalitet er relevant må vi se påstanden i konteksten den var ytret $\mathrm{i}$, nemlig en debatt om foreldre bør ha rett til å ta en informert avgjørelse om de skal ha et barn med Downs syndrom eller ikke (Sørvig 2017; Sterri 2014). En eventuell slik rett er i mine øyne først og fremst forankret i et prinsipp om at foreldrene bør ha et betydelig rom til å ta selvstendige avgjørelser i valg som får store konsekvenser for deres liv og deres familie. Og disse konsekvensene er betydelige i tilfellet Downs syndrom. Et barn med Downs syndrom utgjør både en 
ekstra byrde for foreldrene og for eventuelle andre barn de måtte ha (Bourke mfl. 2008; Hauser-Cram, Warfield, Shonkoff og Krauss 2001), og strider med mange foreldres ønske om et friskt barn med normal funksjonsevne; med andre ord et barn med høyere livskvalitet. Skal vi forhindre foreldrene i å bestemme selv om de vil ha et barn med Downs syndrom eller ikke, må vi ha tungtveiende grunner for det.

Én slik grunn kan være at vi risikerer å få et samfunn uten mennesker med Downs syndrom, hvis tilstrekkelig mange kvinner tar abort. Isolert sett er imidlertid ikke det et stort tap. Intuitivt kan vi vise det med følgende tankeeksperiment: Om vi kunne ta i bruk en vaksine som sørget for at ingen ble født med Downs syndrom, så ville vi gjort det (Sterri 2014). I en vesentlig forstand kan en til og med si at et samfunn hvor ingen blir født med Downs syndrom, er bedre, gitt at et likt antall mennesker blir født. Den mest plausible forklaringen på det er at når vi sammenlikner to liv som begge kan eksistere, er det bedre om det livet som har best mulighet til å leve et godt liv, får leve (se Savulescu 2001; Parfit 2017). ${ }^{6}$

Magelssen kritiserer imidlertid, med rette, dette argumentet for å ikke ta tilstrekkelig hensyn til midlene vi tar i bruk for å komme til et samfunn uten Downs syndrom (Sollien 2017a). Magelssen vedgår at det ville vært bedre om vi kunne tatt i bruk en vaksine for å unngå at barn ble født uten å ha Downs syndrom, men er likevel motstander av selektiv abort. ${ }^{7}$ En vesentlig forskjell er selvfølgelig at det ene innebærer abort, og hvis abort anses som mord, så vil det være galt å frembringe en ellers ønsket tilstand på denne måten. ${ }^{8}$

Hvorvidt abort er mord eller ikke, er imidlertid ikke Magelssens poeng. Han mener vi bør fjerne abortlovens paragraf 2 c, som gir rett til abort etter uke 12 hvis fostre har fătt påvist en "alvorlig sykdom", fordi den er "diskriminerende". Loven "innfører [... nemlig] en gradering av retten til liv, ut fra fosterets egenskaper." (Sollien 2017a) ${ }^{9}$

Den mest nærliggende forklaringen på hvordan abortloven graderer "retten til liv, ut fra fosterets egenskaper", er at fostre uten alvorlige sykdommer har en større grad av beskyttelse etter abortloven. En annen måte å si dette på er at vi tillegger fostre på samme stadium i utviklingsløpet, ulik moralsk status ut fra om de regnes for å ha en "alvorlig sykdom". Det er imidlertid ikke klart at dette er den mest naturlige måten å forstå loven på. En måte å begrunne paragraf $2 c$ på er at kvinner som har fått påvist alvorlig sykdom hos fosteret, bør ha et ekstra vern i møte med nemnda. Siden et barn med psykisk utviklingshemming presumptivt vil utgjøre en ekstra byrde, kan en paragraf som gir rett til abort i slike tilfeller - uten at en trenger å foreta en helhetlig vurdering av kvinnens situasjon - rettferdiggjøres av hensyn til å forenkle abortprosessen og forhindre å pålegge kvinner en ekstra byrde i en allerede vanskelig situasjon, og dermed ikke si noe om moralsk status (Sundby, Løkeland og Schultz 2018).

Selv om en skulle vedgå at paragraf $2 c$ er et uttrykk for urimelig forskjellsbehandling, kan denne innvendingen tale for å utvide tilbudet om selektiv abort ved å tilby kvinner blodprøven NIPT, som gjør det mulig å få mer presis informasjon om fosteret har Downs syndrom og andre trisomier før uke 12. Om en slik blodprøve var på plass, kunne paragraf $2 c$ gjøres overflødig. Kvinner kunne dermed fa tilgang til selektiv abort uten at det ga opphav til noen urimelig 
diskriminering. Et alternativ er å utvide grensen for selvbestemt abort til et senere tidspunkt (Sterri 2017b).

En annen vri på Magelssens innvending er at den store mengden selektive aborter som muliggjøres av abortloven og fosterdiagnostikk, "formidler at personer med Downs syndrom har lavere moralsk verdi enn andre" (Sollien 2017; se også Hofmann 2017; Slagstad og Hofmann 2017). Legg merke til at dette ikke er en påstand om intensjonen til lovgiver eller kvinnene som tar abort, men om hvordan lovverket og handlingene oppleves (se også Solberg 2008). Det er således en bivirkning, forventet eller ei, av loven slik den er utformet i dag.

Det er definitivt grunn til å bekymre seg over ubehaget personer med Downs syndrom kan oppleve ved å vite at mennesker med deres diagnose blir valgt bort $\mathrm{i}$ fosterlivet på grunn av denne diagnosen, og at staten legger til rette for dette gjennom fosterdiagnostikk og abortlovens paragraf 2c. Det virker imidlertid urimelig å konkludere med at dette rettferdiggjør et forbud mot å ta i bruk mer presis fosterdiagnostikk, som NIPT, eller å frata kvinner muligheten til abort på det grunnlaget. ${ }^{10}$ Hvis mennesker med Downs syndrom anså det som en nedvurdering av deres moralske status at vi tilbød en potensiell vaksine til kvinner som forhindret ytterligere mennesker med Downs syndrom å bli født, ville ikke det stoppet oss fra å tilby denne vaksinen. Vi ville snarere forsøkt å understreke at selv om vi forsøker å unngå at flere mennesker blir født med Downs syndrom, anser vi ikke mennesker som har Downs syndrom, for å være mindre verdt (Sterri 2017b).

Magelssen påpeker at forskjellen her er at vi i det ene tilfellet avslutter livet til mennesker med Downs syndrom i fosterstadiet, mens vi i tilfellet med vaksinen bare forhindrer mennesker med Downs syndrom fra å bli født. ${ }^{11}$ Jeg er enig i at det gjør signalet om ulik moralsk verdi sterkere. Jeg vil imidlertid fastholde at skaden knyttet til signaleffekten ikke bør regnes til å være tungtveiende nok til å forhindre kvinner fra å ta informerte valg om de vil ha et barn med Downs syndrom eller ikke. Jeg innrømmer imidlertid at jeg ikke har noen annen vei ut av denne uenigheten enn å appellere til folks intuisjoner.

En siste innvending mot å tilby selektiv abort er at vi bør være et inkluderende samfunn som tar vare på de mest sårbare blant oss. Noen vil si at et samfunn som sorterer vekk sine svakeste, er et samfunn vi ikke kan leve med. Jeg er åpen for at det er noe i denne innvendingen, men det er et dårlig argument for å innskrenke kvinners rett til abort. Hvis flere barn med Downs syndrom blir født som følge av en politikk som begrenser kvinners mulighet til å ta abort, skyldes det ikke at vi er blitt et mer inkluderende samfunn, men bare at noen er tvunget til å få barn de ellers ikke ville fått. Skal vi være et inkluderende samfunn som står til navnet, er en bedre løsning å legge så godt til rette for mennesker med Downs syndrom og deres familier at flere vil velge det alternativet. Det er heller ikke gitt at vi bør se antallet selektive aborter som en indikator på hvor inkluderende samfunnet er. Et inkluderende samfunn tar vare på sine mest sårbare. Men siden mange kvinner har legitime grunner til å ta abort om de får vite at et foster har Downs syndrom, selv i et inkluderende samfunn, er det bedre å vurdere hvor inkluderende samfunnet er på andre måter. ${ }^{12}$

En alternativ vri på den samme innvendingen er at det å legge til rette for selektiv abort over tid, vil føre til at vi behandler mennesker med funksjonsnedsettelser dårligere enn vi gjør i dag. Det er en empirisk påstand som ikke bare kan avfeies fra lenestolen. Det er imidlertid grunn til å tvile på om det er 
hold i den. Vi har i over tjue år tilbudt fosterdiagnostikk og tillatt selektiv abort uten at vi har sett en utglidning i retningen av å behandle personer med funksjonsnedsettelser dårligere. Snarere kan det se ut til at vi behandler personer med funksjonsnedsettelser, inkludert personer med Downs syndrom, bedre enn vi noen gang har gjort. Vi kan ikke ta for gitt at den utviklingen vil fortsette, men denne erfaringen viser at det er mulig å holde to tanker i hodet på samme tid; å legge til rette for selektiv abort samtidig som vi tilbyr bedre hjelp til dem som trenger det. ${ }^{13}$

\section{Levde jeg opp til kravene?}

Jeg mener argumentet jeg har presentert for selektiv abort av fostre med Downs syndrom, er plausibelt. Formulert på sitt beste er det et godt eksempel på provokativ filosofi. Det tar klar stilling til et kontroversielt og emosjonelt spørsmål, og kommer med noen kontraintuitive og radikale påstander, som at et samfunn uten mennesker med Downs syndrom ikke er dårligere, eller til og med bedre, enn et samfunn med. Jeg er tydelig på hvilke premisser som legges til grunn, og hvilke implikasjoner det får om vi aksepterer disse. ${ }^{14}$ Det betyr imidlertid ikke at debatten slik den faktisk utartet seg, levde opp til idealet. Jeg vil nå presentere det jeg anser som de største manglene ved mitt bidrag i debatten om fullverdige liv.

\section{Feil 1: Tvetydig og uheldig ordvalg}

Den første feilen var å bruke det tvetydige og misvisende begrepet fullverdig liv. Som Morten Magelssen påpeker: "Det visker ut nettopp det skillet [Sterri] ville opprettholde", mellom moralsk status og livskvalitet (Sollien 2017a). Mange kritiserte, med rette, bruken av begrepet fullverdig liv for dets assosiasjoner til vurderingen av en gruppe menneskers moralske status, grunnet begrepets semantiske likhet med begreper som verdig og menneskeverd. En referanse til fullverdige liv kan derfor tolkes som en påstand om at noen ikke er et fullverdig medlem av menneskeheten (Sollien 2017b). Når begrepet ble brukt i et argument for selektiv abort etter uke 12, er det forståelig at flere trakk den slutningen, siden en vesentlig del av debatten om abort handler om fosterets moralske status. ${ }^{15}$

Dette begrepet fikk så sterkt feste i folks sinn at det gjorde det vanskelig å bevege debatten videre. Jeg opplevde derfor gang på gang å måtte gå tilbake til start for å oppklare hva jeg mente med fullverdige liv. Det hjalp nok heller ikke at noen, mest åpenbart Norsk Forbund for Utviklingshemmede (NFU), hadde en interesse i å portrettere mitt standpunkt som mest mulig provoserende og sårende, som et ledd i det som vanskelig kan oppfattes som noe annet enn en interessekamp mot fosterdiagnostikk og abortlovens paragraf 2c.

Dette får også fram det vanskelige med å drive provokativ offentlig filosofi spesielt og offentlig filosofi generelt. En møter ikke bare kritikk for kvaliteten på ens argumenter, men må forholde seg til en rekke aktører med interesser i saken, som ikke nødvendigvis er opptatt av å komme fram til sannheten.

\section{Feil 2: Mangelfull begrunnelse for livskvalitet}

At debatten igjen og igjen kom tilbake til betydningen av fullverdige liv, kan også skyldes at jeg ikke ga tilstrekkelig gode og entydige svar på hva jeg egentlig la i begrepet. 
Som presisert ovenfor, var påstanden om at personer med Downs syndrom ikke lever fullverdige liv, utelukkende ment å si noe om hvor godt livet er for dem. At det å leve med en psykisk utviklingshemming er en begrensning av et godt levd liv, tok jeg i utgangspunktet som en selvfølge. Som Inga Bostad (2017) presist formulerte det: "Du gjentar det som synes å være mer enn et premiss hos deg, kanskje nærmere en utgangshypotese (?), nemlig at livet med (eller som) psykisk utviklingshemmet ikke ser ut til å være like bra som et liv uten." Jeg mener fortsatt at dette er en plausibel påstand. En måte å sannsynliggjøre den på er å spørre om vi ville kurert Downs syndrom i fosterlivet hvis vi kunne det, av hensyn til barnet som vil vokse opp. Hvis svaret er ja, så mener vi at egenskap Y står i veien for at $\mathrm{X}$ lever et godt liv. ${ }^{16}$

$\AA$ styrke våre intuisjoner er imidlertid ikke tilstrekkelig. Med tanke på uenighetene som viste seg i løpet av debatten, kan det virke som om vi trenger en tykkere teori om livskvalitet enn jeg la til grunn. Som Bostad (2017) etterspurte i debatten: "Hva slags begrep om livskvalitet bygger du på?" Jeg forsøkte så langt jeg kunne å unngå å belage konklusjonene på én teori om livskvalitet, da disse alltid vil være kontroversielle. Jeg forsøkte heller å peke på egenskaper jeg tenkte vi alle kunne enes om er relevante for å leve gode liv, som "vår rasjonalitet, vår evne til å styre våre liv og evne til å søke sannhet" (Sterri 2017c). Som Espen Gamlund (2017) påpekte, fremstår imidlertid denne listen som "unødvendig intellektualistisk". Poenget mitt er imidlertid ikke at det beste livet er et liv hvor vi søker sannhet og dyrker rasjonaliteten, men at dette er primærgoder som gjør det mulig å leve et godt menneskeliv, uansett hva vi måtte finne verdifullt. Listen var heller ikke ment å være uttømmende, men bare beskrive de egenskapene hvor det å ha Downs syndrom virker begrensende sammenliknet med et liv uten Downs syndrom. I et svar til Bostad forsøkte jeg også å sannsynliggjøre at Downs syndrom vil slå negativt ut i de fleste plausible filosofiske teorier om det gode liv. Den analysen ble imidlertid alt for rudimentær (Sterri 2017a).

I etterkant ser jeg den manglende utdypningen av hva jeg mente med et fullverdig liv, som en stor mangel i debatten. Her skulle jeg trolig heller tatt tyren ved hornene og presentert min forståelse av hva som skal til for å leve et godt liv, og akkurat hvordan jeg mente Downs syndrom ikke levde opp til det, fremfor å henspille på det jeg trodde var felles intuisjoner.

At debattklimaet ble såpass betent, gjorde det trolig mindre attraktivt for andre å kaste seg inn i debatten for å bøte på mine mangler. Ideelt sett skulle en forvente at et fellesskap av tenkere kunne videreutvikle tankene om hvilke liv som er gode, men dette skjedde dessverre i liten grad. Hederlige unntak er Espen Gamlund (2017), som presenterte en teori om fullverdige liv på bloggen politiskfilosofi.no, og Morten Magelssen, som presenterte en dydsetisk forståelse av et godt liv (Sollien 2017a).

\section{Feil 3: Manglende kontekstualisering}

Det fremkom heller ikke klart for dem som leste intervjuet med Minerva, hvorfor det i det hele tatt var relevant å bruke livskvaliteten til personer med Downs syndrom som et ledd i argumentasjonen for selektiv abort, eller hvorfor det var relevant å sammenlikne abort av fostre med Downs syndrom med abort av homofile fostre $\mathrm{i}$ et hypotetisk scenario. Her fikk intervjuformatet vist sin begrensning når en tar opp kompliserte tema. De delene av resonnementet som 
kom på trykk, ble presentert i en form som er alt for innforstått, og som begrenset seg til et lite moment i diskusjonen om selektiv abort, slik at dets plass i den større argumentasjonsrekken ble uklar. Selv om essayet "Et forsvar for sorteringssamfunnet" (Sterri 2014), hvor jeg presenterer argumentet i sin helhet, ble vist til som bakgrunn for samtalen, hjalp det lite. En lærdom er at hver tekst må stå på egne ben, og at intervjuformatet trolig er mindre egnet for å presentere kompliserte argumentasjonsrekker sammenliknet med essay, kronikker, radio og podcast.

Slik jeg ser det, representerer disse feilene mangler i utførelsen av provokativ offentlig filosofi. Mitt bidrag sviktet på kriteriene om klar tale (feil 1), evne til å underbygge premissene (feil 2) og klargjøringen av hvilke premisser som var relevante, og hvordan de hang sammen (feil 3). Feilene skyldes altså ikke direkte utførelsen av provokativ offentlig filosofi, men derimot mangelfull utførelse. Når det er sagt, så medførte mine feil mer bråk og skade fordi de ble koblet med et provoserende budskap og en provoserende begrepsbruk. Hadde jeg begått lignende feil $i$ en diskusjon om et mindre ømtålig tema, ville det skapt mindre oppmerksomhet. Slik henger mine feil sammen med provokativ offentlig filosofi.

En måte å se det på er at provokativ offentlig filosofi er en høyrisikostrategi. Utføres den på en dårlig måte, så fører den med seg mye mer skade enn hvis en utfører varsom offentlig filosofi på en dårlig måte. Det velter bevisbyrden over på provokativ offentlig filosofi siden utførerne av den tross alt vil være mennesker, og vi ikke kan unngå at mennesker vil feile. Det må derfor være flere fordeler knyttet til denne måten å drive filosofi på. Jeg returnerer til fordelene nedenfor. Først vil jeg imidlertid skissere opp noen innvendinger mot provokativ offentlig filosofi som ble trukket fram i løpet av debatten om fullverdige liv, og som jeg tror har generell gyldighet.

\section{Innvendinger mot provokativ filosofi}

En grunn til å være varsom i offentligheten er at provoserende offentlig filosofi kan ende med å skape så mye støy at debattene sporer av. Kravene om at rektor tok avstand fra ytringene mine, og at personer med mine holdninger ikke burde få stipendiatstillinger, og til en viss grad debatten om debatten, skapte støy og vridde debatten vekk fra substansielle spørsmål. Hvis debatter skaper støy, er de mindre effektive i å få folk til å tenke annerledes, som jo er målet med geskjeften. Gitt at dette er en forutsigbar konsekvens av provokativ offentlig filosofi, kan det gi oss grunn til å foretrekke en norm om varsom offentlig filosofi. Det er også en fare for at provoserende filosofi vil forhindre varsomme filosofer fra å delta.

En annen innvending går på filosofers kompetanse. Provokativ offentlig filosofi kommer med klare konklusjoner om praktiske forhold. Det forutsetter at filosofer beveger seg utenfor sitt ekspertområde, og belager seg på empirisk forskning. Det er det en fare for at de vil gjøre dårlig. Om filosofer heller begrenset seg til å komme med betingede påstander, som "gitt at $\mathrm{X}$ er slik, så bør vi gjøre $\mathrm{Y}^{\prime}$, og utforske de ulike sidene av saken og vise sakens kompleksitet framfor å forenkle og konkludere, ville det gjort den offentlige samtalen bedre. Hvert fag kunne dermed ha bidratt med sine styrker, og folk flest kunne deretter gjort seg opp en mening selv. En kan også si at det ville være mer demokratisk, siden filosofer dermed ikke tar på seg 
rollen som filosofkonger, slik de provoserende offentlige filosofene tilsynelatende gjør.

En slik arbeidsdeling kan også være bedre for å forvalte tilliten folk har til akademia. Tilliten til akademikere er en skjør, men svært viktig ressurs. Hvis filosofer opptrer for imperialistisk og skråsikkert, kan det svekke folks tillit til filosofer og akademikere mer generelt. Noe jeg fikk erfare i løpet av debatten om fullverdige liv, er at folk fortsatt setter sin lit til akademia. Hadde ikke jeg tilfeldigvis blitt stipendiat dagen etter at Minerva-artikkelen ble publisert, men heller fortsatt vært kommentator i Dagbladet, er det svært sannsynlig at uttalelsene ikke hadde fått samme oppmerksomhet. Et tegn på det er at mye av kritikken gikk eksplisitt på min universitetstilknytning. Det er et godt tegn. Det betyr at mange stoler på akademia som institusjon og den sertifiseringen av fagfolk som universitetet står for. At folk kan sette sin lit til at akademikere har en særegen ekspertise det er verdt å lytte til, har en stor verdi når folk skal gjøre seg opp en mening om hvordan tingenes tilstand er, og hva de bør gjøre. Men det gjør også at akademikere har en forpliktelse til å ikke skalte og valte med den tilliten. Gitt at folk bruker statusen som akademiker som en tommelfingerregel når de gjør seg opp meninger, så kan en slik grenseoverskridende atferd både innebære lånt og illegitim autoritet, samtidig som det potensielt kan redusere brukbarheten til signalet om at akademikere har en særegen ekspertise det er verdt å lytte til.

En tredje innvending er at noen ytringer kan ha skadelige konsekvenser. Flere påpekte likhetene mellom idégodset som fikk meg til å rangere noen liv som bedre enn andre, og eugenikken, en idé og praksis som hang tett sammen med nazismens tankegods og drapet på personer med funksjonsnedsettelser (L Grue 2017; Egeland 2017; Aavitsland og Oftestad 2017). Mindre dramatisk, men likevel svært alvorlig, er påstanden om at det å rangere menneskeliv truer ideen om at alle mennesker er like mye verdt, at de har det samme menneskeverdet, en idé som har stått som bolverk mot dårlig behandling av sårbare grupper etter andre verdenskrig (Bostad 2017). Siden ideer om likeverd er så grunnleggende for vår kultur, bør filosofer unngå å utfordre slikt tankegods.

Et siste hensyn som taler for varsomhet, er at våre ytringer kan såre, og i verste fall passivisere. Bostad (2017) ser ut til å mene at det er viktigere at personer med utviklingshemming blir tatt på alvor som mennesker med eget livsengasjement, enn at akademikere ytrer seg om deres liv på en måte som virker objektiviserende og muligens passiviserende. Provokativ offentlig filosofi kan, slik hun ser det, true menneskers "subjektstatus". Hun spør derfor om noen debatter og synspunkter heller hører hjemme i akademiske seminarer enn i det offentlige rom.

\section{Et forsvar for provokativ offentlig filosofi}

\section{For mye støy}

Det kan ikke være tvil om at debatten om fullverdige liv skapte mye støy. Til tross for at denne debatten ble spesielt betent, trolig grunnet bruken av begrepet fullverdige liv, er støy en forventet konsekvens av provokativ filosofi.

Hvorvidt det taler for en norm om en mer varsom offentlig filosofi, avhenger imidlertid av om en del støy er verdt prisen vi betaler for godene vi kan få av provokativ offentlig filosofi. Provokativ offentlig filosofi vekker ofte mer oppmerksomhet og skaper mer engasjement enn det vanlige tilfellet av varsom offentlig filosofi. Når filosofer utfordrer etablerte sannheter og kommer med klare 
formaninger om hva vi bør gjøre, blir filosofien relevant for folk. Provokativ offentlig filosofi passer også bedre med medievirkeligheten, som heller belønner klare budskap og oppfordring til handling, enn varsom offentlig filosofi som forsøker å presentere kompleksiteten i en sak. Noen vil si at det er et problem med mediene slik de opererer i dagens forbrukersamfunn, men det er grunn til å tro at mediene i dette tilfelle i stor grad speiler folks dypereliggende preferanser. Det er en grunn til at debattredaktører etterspør argumenterende tekster, med en tydelig motstander, en klar moral og oppfordring til handling. Det er det vi leser, og det er det som engasjerer oss til å ta del i debatten, over middagsbordet, på sosiale medier eller i avisen. Det er ikke uten grunn at filosofen Peter Singer, som er et eksempel på en spesielt argumentativ og utfordrende filosof, blir mer lest enn de fleste andre filosofer.

Selv debatten om fullverdige liv, som genererte svært mye støy, ga opphav til en rekke interessante bidrag innen områder som metaetikk og normativ etikk (Andresen 2017; Lindstad 2017), og flere gode bidrag som belyste spørsmålet om selektiv abort fra flere sider (Sollien 2017a; Magelssen 2017; Gamlund 2017; J Grue 2017). Debatten var også utgangspunktet for en til tider konstruktiv metadebatt (Bostad 2017; Hofmann og Carson 2018), som denne artikkelen er en forlengelse av.

Mer generelt er det verdt å minne om at en debatt som genererer 80 prosent støy, likevel kan gi mer innsikt hvis de resterende 20 prosentene utgjør et større antall medieoppslag, eller gjør et mer varig inntrykk, enn hvis en hadde valgt en annen framgangsmåte, uten at jeg dermed vil anbefale en slik fordeling. 80 prosent støy skaper ikke bare ineffektiv formidling. Det bringer med seg en rekke andre uheldige konsekvenser, som vi vil returnere til nedenfor. For nå er poenget at en forventning om støy ikke er nok til å senke provokativ offentlig filosofi, da denne formen for offentlig filosofi vil ha en større tilbøyelighet til å treffe folk.

Det åpner imidlertid for en annen innvending, nemlig at provoserende filosofer tar opp plass fra mer varsomme filosofer. Denne innvendingen hviler imidlertid på en urealistisk antagelse om at filosofers plass i offentligheten er et nullsumspill. Det er mer plausibelt at provoserende filosofers deltakelse åpner opp rommet for varsomme filosofer. Debatten om fullverdige liv er et eksempel på det. Den gjorde at etterspørselen etter filosofisk innsikt økte.

På lengre sikt er det grunn til å tro at denne positive effekten vil forsterkes. Jo mer tilstedeværende filosofien er i offentligheten, jo mer relevant vil den oppleves, og jo mer vil filosofers ekspertise etterspørres. Også her er det grunn til å tro at provokativ offentlig filosofi vil stå sterkere enn varsom offentlig filosofi. Filosofer er nødt til å konkurrere om oppmerksomheten med andre tilbydere av kunnskap som er relevant for folk i deres egen hverdag og for deres politiske engasjement. Siden provokativ offentlig filosofi søker å gi klare svar på problemer som er presserende, og utfordre konsensus, gjør det filosofien mer relevant. Når folk blir vant til at filosofi er en konstruktiv disiplin, som gir dem et rammeverk til å tenke om hvordan de bør leve sitt eget liv, og hvordan vi bør fatte kollektive avgjørelser, er det grunn til å tro at etterspørselen etter filosofisk innsikt vil øke.

Men vil et offentlig ordskifte preget av provokativ offentlig filosofi på lang sikt bli så ugjestmildt at mer varsomme filosofer vil unngå å ta del i det? ${ }^{17}$ Det er som nevnt en viss risiko knyttet til menneskelige feil, som gjør at provokativ offentlig filosofi kan bli ubehagelig eller for konfronterende. Vi bør imidlertid ikke 
overdrive denne faren. Provokativ offentlig filosofi skal være saklig, argumenterende og ta ballen, ikke mannen. Det jeg mistenker gjør det offentlige ordskiftet til et ugjestmildt sted å være, er ad hominem-angrep, usakligheter og en manglende vilje til å utdype hva en egentlig mener.

Som nevnt medfører menneskelige feil i utøvelsen av provokativ offentlig filosofi noen ulemper. Det er imidlertid også en risiko knyttet til å ikke ta den i bruk. Varsomhet innebærer en form for selvsensur i det godes tjeneste. Det kommer vi heldigvis ikke utenom. Vi bør være høflige og, så langt vi greier, unngå å skape unødvendig ubehag. Problemet oppstår hvis denne normen går for langt, og sanksjoneres strengt av kollegaer og tilhørere. Det er nemlig en systematikk i hvilke ytringer vi anser som potensielt provoserende og sårende, avhengig av hvem vi identifiserer oss med. Siden vi også lytter mer til dem vi identifiserer oss med (Sunstein 2012, Kahan 2012), risikerer vi å stilne de menneskene som har størst evne til å få folk til å lytte til nye argumenter og bevis, og som dermed er best egnet til å fungere som epistemiske brobyggere mellom grupper. For å unngå ekkokammer og polarisering av offentligheten trenger vi derfor mennesker som tør å bryte med konsensus innad i gruppen. For det trenger vi normer som ikke oppfordrer til for mye varsomhet.

Det er også grunn til at en norm om varsomhet over tid vil være selvforsterkende. Hvis de mest kontroversielle påstandene forsvinner fra ordskiftet, vil de nest mest kontroversielle påstandene bli de mest kontroversielle, og slik kan det fortsette. Det er også grunn til å tro at folks oppfatninger av hva som er støtende og krenkende, til dels er en funksjon av hvor vant de er til å høre kontroversielle meninger. Hvilke ytringer som skaper støy, vil derfor endres over tid. Selv om vi skulle evne å få på plass en norm som i første rekke bare begrenser de mest kontroversielle meningene som i sum er negative for det offentlige ordskiftet, er det derfor en risiko for at den over tid vil begrense ytringer som en ikke mente å begrense, og som i sum er positive.

\section{Bør filosofer være imperialistiske?}

Det virker umiddelbart rimelig at ulike mennesker fra ulike fagdisipliner unnlater å komme med for bastante meninger om fagfelt de ikke er eksperter innen. Psykologer bør ikke uttale seg bastant om kjemi, og fysikere bør ikke uttale seg bastant om økonomi, i den grad de uttaler seg som fagfolk.

Hvorvidt dette også gjelder filosofer som baserer sine argumenter på empiri fra andre fagdisipliner når de kommer med uttalelser om hva vi bør gjøre, avhenger av hvilken rolle vi mener offentlig filosofi bør spille. Jeg tror for det første vi trenger en eller flere disipliner som tar på seg jobben med å syntetisere kunnskap fra ulike fagdisipliner, og ta det overordnede, gjerne normative, blikket; gitt det vi nå vet, her bør vi gå. Det er ikke nødvendig for mitt argument at filosofi er disiplinen som evner å gjøre dette på en best mulig måte. Jeg vil imidlertid holde fast ved at vi trenger at noen spiller en slik integrerende rolle, og at filosofi er i en god posisjon til å fylle den.

For det første er filosofien en grenseløs disiplin som omhandler det grunnleggende ved andre fagdisipliner. Filosofien, med sin vekt på begrepsmessig klarhet, logikk og analytisk tenkning, har for det andre gode redskaper for å spille en altomfattende rolle. ${ }^{18}$ Det er en svært krevende oppgave, og det er derfor synd at ikke filosofer får en bedre innføring i empirisk forskningsmetode som del av 
utdanningen. ${ }^{19}$ Men det er ikke alltid at den vanskeligste jobben er å basere sine standpunkter på innsikt fra de empiriske disipliner.

Ta debatten om fullverdige liv som eksempel. Her er den vanskeligste jobben filosofisk. Hva inngår i vurderingen av et godt liv? Er det konstituert av summen av de gode og dårlige opplevelsene? Eller er et godt menneskeliv konstituert av arbeidet for og/eller oppnåelsen av enkelte typer goder, som kunnskap, dype mellommenneskelige relasjoner, mening eller bidrag til et kollektivt gode? For denne diskusjonen er poenget at det ikke, av hensyn til kompetanse, er grunn til at filosofer bør avstå fra å foreta vurderinger om andres liv. Snarere er det nettopp den filosofiske kompetansen som det er mest behov for når en skal foreta slike vurderinger.

Det er heller ingen grunn til å tro at filosofer ikke har kompetanse til å trekke klare konklusjoner. Også tilhengere av varsom offentlig filosofi mener at filosofer besitter kompetanse til å trekke på ulike perspektiver, vise fram nyansene i en sak og skissere opp styrker og svakheter ved argumentene på begge sider. Men i den grad filosofer kan gjøre dette, besitter de også kompetansen til å vurdere tyngden til og relevansen av argumentene, for så å konkludere med hva vi har mest tungtveiende grunner til å gjøre.

Om filosofer gjør denne jobben ryddig og gjennomsiktig, er det også liten grunn til å tro at dette vil svekke tilliten folk har til akademikere. Snarere er det grunn til å tro at det vil kunne øke tilliten, siden filosofien viser seg som en relevant og konstruktiv bidragsyter i det offentlige ordskiftet. Dette kan forhåpentligvis også redusere akademikerforakten som finnes i noen miljøer. ${ }^{20}$ Det er i den forbindelse verdt å merke seg populariteten til intellektuelle som Jonathan Haidt, Jordan Peterson og Sam Harris, som er spesielt stor i miljøer som har lite til overs for store deler av akademia. Haidt, Peterson og Harris bedriver alle, i mer eller mindre grad, provokativ offentlig filosofi. Jeg anser det som en lite dristig hypotese at deres popularitet i stor grad skyldes nettopp dette.

Alternativet til at filosofer tar på seg rollen med å vekte argumenter og trekke konklusjoner, er heller ikke at den forblir ubesatt. Det vil alltids være andre som velger å konkludere, om ikke filosofer gjør det. Økonomer står for eksempel ikke tilbake for å rangere liv og gi konkrete råd om hvilken politikk som bør føres, og hvordan knappe ressurser bør fordeles. Ja, det er grunn til å tro at denne framferden er med på å forklare hvorfor økonomi er den dominerende fagdisiplinen i offentligheten (Wolfers 2015).

Det kan innvendes at ingen fagdisiplin $b ø r$ ta på seg rollen med å konkludere, siden det vil være å ta på seg rollen som overdommer. Gitt at folk setter sin lit til akademikere, vil det være udemokratisk om akademikere kommer med bastante konklusjoner i spørsmål som bør regnes som politiske. Akademikere bør begrense seg til å framlegge fakta og vurdere argumenters holdbarhet, ikke konkludere. Dette er imidlertid et merkelig syn på demokratiet. Selv om ingen borgere bør ha en større stemmevekt i valg bare fordi de har mer ekspertise, følger det ikke at det er udemokratisk om velbegrunnede synspunkter i offentligheten legges mer vekt på.

Det kan imidlertid hevdes at filosofers meninger får større innflytelse enn argumentene skulle tilsi, siden folk bruker deres faglige og institusjonelle sertifisering som en heuristikk når de gjør seg opp en mening. Det kan det være noe i, men jeg tror denne effekten er betydelig overdrevet. Svært lite tyder på at 
filosofenes makt, om den tar provokativ eller varsom form, utgjør et demokratisk problem. Snarere kan det være et demokratisk problem at filosofer ikke lyttes mer til. Kanskje gjelder det spesielt provoserende filosofer. For det første vil provokativ offentlig filosofi ofte utfordre majoritetsposisjonen og dermed sjelden ha majoriteten med seg. Det er heller ingen grunn til å tro at folk vil ta bedre informerte valg om akademikere unnlater å vise hvor argumentene leder dem hen. Ofte er det selve vektingen av argumenter som er den vanskeligste jobben. At fagfolk demonstrerer hvordan de foretar denne vektingen, er dermed nyttig informasjon når borgerne skal gjøre seg opp en mening om politiske og etiske spørsmål. Provokativ offentlig filosofi er derfor trolig en ressurs for demokratiet, ikke en trussel mot det.

Provokativ offentlig filosofi kan også sies å demonstrere en viktig demokratisk dyd, nemlig ærlighet om hva en mener overfor folkene en adresserer. Dette er viktig fordi det gjør at filosofer ikke gjemmer seg bak et slør av objektivitet, som de i mange tilfeller ikke vil kunne leve opp til. Hvis en har en privat mening om at selektiv abort er galt, så vil det i mange tilfeller reflekteres i hva en velger å løfte fram, selv om en driver varsom offentlig filosofi. Kanskje vil en løfte fram ett eller to aspekter som taler mot selektiv abort, som at selektiv abort sender et uheldig signal til mennesker som lever med Downs syndrom, uten å foreta en vurdering av alle relevante hensyn. Foruten at dette kan være mindre ærlig, fører det også med seg et annet problem. Det etterlatte inntrykket vil nemlig gjerne være at selektiv abort er galt, selv om den varsomme filosofen ikke presenterte noen helhetlig vurdering av saken.

Provokativ offentlig filosofi er ærlig på en annen måte. En provokativ offentlig filosofi forsøker ikke å kamuflere eller være uklar om de logiske implikasjonene av premissene en legger til grunn. Hvis et forsvar for abort også impliserer spedbarnsdrap, vil en provokativ offentlig filosof være ærlig om det (McMahan 2007; Sterri 2016; 2018). Hvis begrunnelsene for selektiv abort i tilfellet Downs syndrom impliserer at en også måtte ha tillatt selektiv abort av homofile, i en hypotetisk situasjon hvor det var mulig å identifisere hvem som ville blitt født homofile, må implikasjonene tas på alvor, og ikke forkastes som irrelevante (Sørvig 2017; Sterri 2017d). Slik sett vil en provokativ offentlig filosofi ofte gjøre jobben som meningsmotstanderne gjerne gjør, nemlig å vise hvilke potensielt frastøtende implikasjoner som følger av ens syn. Dette er viktig informasjon folk trenger for å gjøre seg opp en mening om hvor attraktivt synet som presenteres, er i sin helhet.

\section{Skadelige ytringer}

Hvis Lars Egeland (2017) har rett i at provokativ offentlig filosofi, som stiller spørsmål ved alle menneskers menneskeverd og rangerer menneskeliv, kan ende i massedrap på psykisk utviklingshemmede, så blekner eventuelle argumenter om fordelene ved denne formen for offentlig filosofi. Det er imidlertid liten grunn til å akseptere en slik påstand. Selv om det skulle være sant at eugeniske ideer var en av flere faktorer som ledet til holocaust, innebærer ikke det at diskusjon av liknende ideer vil lede til en ny holocaust, eller noe i nærheten av dette. Det er heller ikke slik at vi står forsvarsløse mot en slik utvikling. Det er ingen automatikk i at et forsvar for å fremme mest mulig gode menneskeliv før fødsel, gjennom embryoseleksjon eller abort, skulle innebære at en også må forsvare drap på suboptimale liv. Tvert imot er det grunn til å tro at eugeniske ideer har fått 
uforholdsmessig dårlig og mangelfull behandling, nettopp på grunn av deres tilknytning til holocaust (Roll-Hansen 2017).

Men har Bostad rett $\mathrm{i}$ at visse måter å omtale personer på, kan fungere objektiviserende og passiviserende? Det er en alvorlig anklage, som dessverre nok har en del for seg. I et essay i New York Times Magazine beskriver Harriet McBryde Johnson (2003), som selv levde med en funksjonsnedsettelse, om sitt møte med Peter Singer. Hun beskriver en manglende følelse av å bli sett for alt det hun er. I beste fall vil hennes vitnesbyrd om sitt eget liv føre til en marginal oppdatering av Singers syn på et liv med en funksjonsbegrensning. Likeledes, når jeg påstår at Downs syndrom er en begrensning på et godt levd liv, så blir fokuset på funksjonsnedsettelsen, og ikke hele mennesket.

Jeg vedgår at dette er et hensyn som taler mot visse former for provokativ offentlig filosofi, og at denne formen for offentlig filosofi dermed bare kan rettferdiggjøres i den grad den oppnår noe viktig. Hvorvidt dette kriteriet var innfridd i debatten om fullverdige liv, er et åpent spørsmål. Siden en, for alle praktiske formål, kan rettferdiggjøre selektiv abort ved å henvise til at barn med Downs syndrom vil utgjøre en ekstra byrde på foreldrene, så kan det argumenteres for at det var unødvendig å trekke inn livskvaliteten til personer med Downs syndrom. I det minste burde det vært gjort på en mer skånsom måte, og med bedre valg av ord enn det jeg gjorde i denne debatten.

Vi bør imidlertid ikke gjøre den feil å tro at ubehagelige påstander er uten instrumentell verdi bare fordi de er ubehagelige. Hvis tilhengerne av eugenikk har rett i at vi ved hjelp av genredigering vil kunne gjøre at mennesker lever mye bedre liv enn i dag, så er det potensielt en enorm gevinst (Savulescu, Sandberg og Kahane 2011). Og hvis Peter Singer (2009) har rett i at ideen om menneskeverd står i veien for å behandle dyr bedre, kan det potensielt være enormt viktig å erstatte den ideen med et mer inkluderende konsept. Også debatten om selektiv abort er en nødvendig debatt.

Vi har et lovverk som har utpekt Downs syndrom som særskilt grunn for abort, og vi finansierer fosterdiagnostikk til kvinner over 38 år, blant annet for å gi flere kvinner reell mulighet til å ta abort på det grunnlaget. Vi trenger derfor en ærlig og åpen debatt om loven, og endringer i den. Alternativet til en ærlig og potensielt sårende debatt er at lovverket står uten forklaring, og at folk føres bak lyset om de egentlige grunnene for politikken som føres. Det er for eksempel besynderlig å lese komitémerknadene til flertallet i helse- og omsorgskomiteen i evalueringen av bioteknologiloven. Her vedtas det at NIPT skal tilbys alle gravide på Stortinget, blant annet på grunn av at den er mer effektiv i å identifisere trisomi 13 og 18 . At den er nærmest feilfri i å identifisere trisomi 21, Downs syndrom, nevnes ikke av flertallet. Det påpekes at det er en rekke etiske problemstillinger knyttet til det å tilby denne blodprøven, men disse glattes over fremfor å tas på alvor. ${ }^{21}$

Det er først når vi argumenterer eksplisitt, at vi gjør det mulig å ha en ordentlig debatt om hvilke lover vi bør ha, og hvordan vi bør handle. Det er også først når vi viser de fulle implikasjonene av våre argumenter, at det er mulig å ta stilling til holdbarheten av dem. Selv om det er retorisk potent å utelukkende argumentere for abort med å henvise til kvinnens rett til å bestemme over sin egen kropp, er det ikke tilstrekkelig. De fleste er for å legge grenser på kvinners abortrettigheter, enten fordi fosteret har oppnådd en viss modning, eller fordi vi mener det er galt å ta abort på bakgrunn av enkelte egenskaper hos fosteret, som for eksempel kjønn. 
Det er også svært vanskelig å vurdere de langsiktige konsekvensene av å uttale seg på måter som kan såre andre. Det kan være uheldig for dem som blir rammet, men om vi forsøker å følge argumentene dit de leder og konkludere i klartekst, får vi kanskje gevinster som er store nok til å veie opp for den skaden vi påfører. Vi bør derfor være svært varsomme med å sanksjonere en norm som tilsier at vi bør begrense potensielt krenkende ytringer til seminarrommet, slik Inga Bostad (2017) antyder at vi bør. En annen grunn til at vi ikke bør støtte opp om en norm som begrenser ytringer som oppleves sårende, er at det gir interessegrupper et sterkt kort på hånda til å begrense ytringer de ikke liker, eller som passer dårlig overens med deres egne interesser, slik Norsk Forbund for Utviklingshemmede (NFU) forsøkte i debatten om fullverdige liv, ved å politianmelde meg for hatytringer.

Selv om det skulle være ønskelig å begrense en del diskusjoner til akademiske seminarer og fagtidsskrifter, er tiden hvor det var mulig å spare allmennheten for ubehagelige meninger, på den måten forbi. Upubliserte arbeider spres på sosiale medier før de har gått gjennom fagfellevurdering, og vitenskapelige artikler deles, brukes i debatter og omtales i media, uten at forskerne har kontroll på det. Dette opplevde Alberto Giublini og Franscesca Minerva (2012) da de i Journal of Medical Ethics skrev om hvordan argumentene mange av oss fører for selvbestemt abort, impliserer spedbarnsdrap, også av friske fostre, i enkelte tilfeller. At deres konklusjoner var betinget, og i det minste ikke eksplisitt innebar noen støtte til spedbarnsdrap, forsvant i oversettelsen fra akademisk filosofi til nyhetssaker. De trengte derfor ikke å drive provokativ offentlig filosofi for å få mer eller mindre treffende versjoner av sine meninger spredt i offentligheten (Minerva 2014). Også uttalelser i bransjemedier som er ment for et akademisk publikum, kan spres og vris til det ugjenkjennelige når sitater spres videre. Det opplevde Kristian Ekeli da han i et intervju med Univers, universitetsavisa i Stavanger, uttalte seg om hensiktsmessigheten av et forbud mot oppfordringer til terrorhandlinger (Tonstad 2012). I VG (2012) ble uttalelsene presentert under overskriften "Helt greit å oppfordre til terror”. I en slik verden er den eneste garantien man har for å ikke framstå krenkende eller sårende, å unnlate å skrive om temaene overhodet.

Når vi vurderer sannhetssøken opp mot andre verdier, er det også viktig å huske at akademia bare er én av flere samfunnsinstitusjoner. Så selv om vi skulle mene at andre verdier er viktigere enn sannheten, noe som er en høyst plausibel påstand, er søken etter sannheten likevel akademias primære verdi. Det gjelder også, slik jeg ser det, i akademikeres omgang med offentligheten. Akademikere kan sies å ha en forpliktelse til å følge argumentene dit de leder dem, og si ting så klart de kan. Det er det ikke så mange andre offentlige aktører som gjør. Mange har en interesse i å ivareta behagelige fortellinger om menneskeverdets ukrenkelighet og at alle liv er like bra å leve. Kanskje er det, slik Henry Sidgwick (1981) hevdet, gunstig at et samfunn opprettholder slike myter. Jeg vil likevel hevde at det er filosofers jobb å pirke i disse mytene. Hva mener vi med menneskeverd, og er det virkelig ukrenkelig? Er alle liv like gode? Dette er ikke temaer som bør bli doxa, som ikke stilles spørsmål ved. Som John Stuart Mill (2008) påpeker i sitt berømte forsvar for ytringsfriheten: Å unnta noen prinsipper og verdier fra debatt er også den sikreste veien å glemme begrunnelsene for å sette dem så høyt som vi gjør. Det er ikke slik at ethvert angrep på verdiene vi holder høyt, svekker forsvaret av dem; det kan snarere fungere til å vekke folk til å beskytte dem, slik det kan se ut til at debatten om fullverdige liv gjorde. 
Det er enkelte debatter som skaper mer støy og opphetet debatt enn andre. I mange av disse debattene er det også noen som kan føle seg krenket eller misforstått. De er gjerne startet av filosofer som bedriver provokativ offentlig filosofi; som utfordrer konsensus og konkluderer klart om følelsesladde temaer. Det er lett å trekke en slutning fra dette at filosofer bør støtte opp om en norm om å være mer varsom i ens omgang med offentligheten. Jeg har forsøkt å argumentere for at det ikke er hensiktsmessig, verken av etiske eller epistemiske hensyn. Snarere er det grunn til å tro at provokativ offentlig filosofi vil gjøre offentligheten bedre, og demonstrere filosofiens relevans. ${ }^{22}$

\section{Noter}

1 Ifølge W. K. C. Guthrie (2016) er målet med den sokratiske dialogformen utelukkende å oppnå kunnskap om din og din samtalepartners manglende kunnskap. En kan muligens gi det en vri fra Karl Popper og si at den sokratiske metoden handler om falsifisering av teorier, som i det minste gir kunnskap om hvilke teorier som ikke holder. Det er noe fast grunn i at noen teorier er mer standhaftige i møte med kritikk enn de andre.

${ }^{2}$ Siden kommunikasjonsmediet gjerne er aviser, og en ikke har privilegiet av å kunne bore ned i enkeltmenneskers oppfatninger, er kanskje denne differansen mellom sokratisk og provokativ offentlig filosofi i større grad drevet av mediet enn en dyp forskjell mellom de to metodene.

${ }^{3}$ Takk til en anonym fagfellevurderer for å utfordre meg på hvordan provokativ offentlig filosofi forholder seg til sokratisk filosofi. Takk også til Espen Gamlund for å presse meg til å få fram at den faktiske praksisen i offentlig filosofi er mer komplisert enn min inndeling i provokativ og varsom offentlig filosofi kan gi inntrykk av.

${ }^{4}$ Se Agnieszka og Tannenbaum (2018) for en diskusjon av moralsk status.

${ }^{5}$ På enkelte områder skårer imidlertid barn med Downs syndrom bedre enn den normale populasjonen (se Xanthopoulos mfl. 2017)

${ }^{6}$ En alternativ teori er at det er hensynet til den totale velferden som gjør seg gjeldende. Under forutsetningen om at et liv uten Downs syndrom innehar mer velferd enn et liv med, vil den totale velferden være større i scenarioet hvor ingen mennesker med Downs syndrom fødes, så lenge antall individer holdes konstant. Dette synet leder imidlertid til kjente problemer, som "den frastøtende konklusjonen", hvor en verden bestående av en enorm mengde mennesker med marginalt positiv livskvalitet anses for å være bedre i kraft av dens større totale velferd, enn en verden med færre, men likevel svært mye lykkeligere, mennesker (Parfit 1984, del 4; se også Sterri 2017c; Lindstad 2017).

${ }^{7}$ Personlig kommunikasjon.

${ }^{8}$ Selv mener jeg abort før uke 20 ikke er å regne som en moralsk relevant skade på fosteret, grunnet at kapasiteten for bevissthet ikke er utviklet (se bl.a. Sterri 2016; 2018; McMahan 2002). I en tekst i Klassekampen i anledning debatten om fullverdige liv presenterer Jens Saugstad (2017) et alternativ grunnlag for den moralske statusen, forankret i Aristoteles og Kant, nemlig fornuftsevnen, som muligens utvikles mellom uke 20 og 28 når storehjernen utvikles. Slik jeg ser det, 
er det ingenting i denne diskusjonen som står og faller på om vi velger fornuftsevnen eller kapasiteten for bevissthet som grunnlaget for moralsk status.

${ }^{9}$ Argumentet er opprinnelig fremført i Magelssen og Materstvedt (2013).

${ }^{10}$ Hofmann og Slagstad (2017) kritiserer meg for å ikke foreta en helseøkonomisk vurdering av om alle kvinner bør få tilgang til blodprøven NIPT. Jeg er enig i at vi bør foreta en helseøkonomisk vurdering før vi skulle tilby alle kvinner en blodprøve. Mitt poeng er imidlertid ikke å komme med en vurdering av kostnaden og nytten til et spesifikt tilbud sett opp mot alle andre tilbud vi gir i helsevesenet i dag, men å vise at vi som samfunn ikke har gode moralske grunner til å forhindre gravide kvinner å få tilgang på denne informasjonen. Om det er god bruk av pengene våre, er en annen sak.

${ }^{11}$ Personlig kommunikasjon

${ }^{12}$ Takk til Espen Gamlund for denne presiseringen.

${ }^{13}$ Takk til Nils August Andresen for å minne meg på denne innvendingen.

${ }^{14}$ Det vil selvfølgelig alltid finnes andre innvendinger som ikke er behandlet, som i teorien kan endre konklusjonen. Slik sett er alle konklusjoner tentative. For eksempel vil noen si at det å tilby eller foreta selektiv abort, står i kontrast til en dyd om å elske barnet sitt uavhengig av deres egenskaper. Jeg finner imidlertid ikke denne innvendingen spesielt plausibel. Den vil for det første innebære et nei til all form for selektiv abort, også i tilfelle trisomi 18, noe svært få vil ønske. For det andre synes det ikke som om foreldre som har forventninger om spesielle egenskaper ved barna og hvordan disse egenskapene utvikles, ikke lever opp til idealene for en god forelder. Takk til Morten Magelssen for å presisere at konklusjonen min slik sett er tentativ, og for å presentere eksemplet, som er hentet fra Magelssen m. fl. (2018).

${ }^{15}$ Se imidlertid Thomson (1971) for et argument om at abort bør tillates selv om fosteret betraktes som en person med fulle rettigheter.

16 Se Harris (2001) for et liknende syn på hva som kvalifiserer som funksjonsnedsettelse.

${ }^{17}$ Takk til en anonym fagfellevurderer for denne utfordringen.

${ }^{18}$ Se Bostrom (1997) for et forsvar for en imperialistisk filosofi.

${ }^{19}$ Det er imidlertid noen retningslinjer en kan forholde seg til. En bør, så langt det lar seg gjøre, basere konklusjonene sine på så lite kontroversielle empiriske premisser som mulig, og på metastudier og litteraturgjennomganger framfor enkeltstudier. Hvis en er nødt til å basere seg på enkeltstudier, bør en foreta en kritisk gjennomgang av kvaliteten på studiene, helst i samarbeid med forskere på feltet, og en må for all del ikke velge seg studier av hensyn til om de støtter opp om ens foretrukne hypotese eller ikke.

${ }^{20}$ Akademikerforakten er ikke helt uten grunnlag. Bernard Williams (2012: xvii) beskrev i 1972, i innledningen til boka Morality, tilstanden innenfor moralfilosofi på følgende måte: "Contemporary moral philosophy has found an original way of being boring, which is by not discussing moral issues at all." Takk til Morten Magelssen for tips.

${ }^{21}$ Et representativt eksempel fra merknadene er: "Flertallet anerkjenner at debatten om innføring av NIPT-testen, ja fosterdiagnostikk generelt, kan oppleves krenkende for dem som har barn som er annerledes, og frykten for misbruk av kunnskap og sorteringssamfunnet er høyst reell... Flertallet mener likevel det er vanskelig, og heller ikke ønskelig, å stoppe store viktige fremskritt innen 
helseforskningen, men at det må være strenge reguleringer og tydelige etiske debatter rundt de mulighetene ny forskning åpner opp for." (Stortinget 2018)

${ }^{22}$ Finansiert gjennom Norges forskningsråds-prosjektet "What should not be bought and sold?" (Prosjektnummer 259521). Jeg har nytt godt av kommentarer fra Espen Gamlund, Morten Magelssen, Nils August Andresen, Ole Martin Moen og en anonym fagfellevurderer. Takk for det.

\section{Referanser}

Aavitsland, K. B., Oftestad, E. A. (2017, 21. april). Hvor skal vi flytte grensen, Sterri? Klassekampen. Hentet 16. september 2018 fra http://www.verdidebatt.no/ innlegg/11682698-hvor-skal-vi-flytte-grensen-sterri?side=1.

Agnieszka, J., Tannenbaum, J. (2018). The Grounds of Moral Status. I Zalta, E. N. (red.), The Stanford Encyclopedia of Philosophy (Vår 2018-utgaven). Hentet 15. september 2018 fra https://plato.stanford.edu/archives/spr2018/ entries/grounds-moral-status/.

Andresen, N. A. (2017, 6. juni). Singer, fiksjonen og menneskeverdet. Minervanett. Hentet 28. mai 2018 fra https://www.minervanett.no/singer-fiksjonen-ogmenneskeverdet/.

Bertoli, M., Biasini, G., Calignano, M. T., Celani, G., De Grossi, G. , Digilio, M. C., ... Zuccalà, G. (2011). Needs and challenges of daily life for people with Down syndrome residing in the city of Rome, Italy. Journal of Intellectual Disability Research, 55(8): 801-820. https://doi.org/10.1111/j.13652788.2011.01432.x.

Bostad, I. (2017, 12. mai). [Bidrag i] Hva er et menneske verdt? Morgenbladet, 8 11.

Bostrom, N. (1997). Predictions from Philosophy? How philosophers could make themselves useful. Hentet 28. mai 2018 fra https://nickbostrom.com/old/ predict.html

Bourke, J., Ricciardo, B., Bebbington, A., Aiberti, K., Jacoby, P., Dyke, P., ... Leonard, H. (2008). Maternal physical and mental health in children with Down syndrome. The Journal of Pediatrics, 153(3): 320-326. https://dx.doi.org/10.1016\%2Fj.jpeds.2008.02.047.

Egeland, L. (2017, 19. april). Akademia og rasehygiene. Khrono. Hentet 28. mai 2018 fra https://khrono.no/debatt/akademia-og-rasehygiene.

Foley K. R., Bourke, J., Einfeld, S. L., Tonge, B. J., Jacoby, P., Leonard, H. (2015). Patterns of depressive symptoms and social relating behaviors differ over time from other behavioral domains for young people with Down syndrome. Medicine (Baltimore), 94(19): e710. https://dx.doi.org/10.1097/ MD.0000000000000710.

Frankfurt, H. (2005). On Bullshit. New Jersey, Princeton University Press.

Gamlund, E. (2017, 25. april). Hva er galt med sortering? Noen merknader til debatten om abort og Downs syndrom. Hentet 15. september 2018 fra http://polfilos.tumblr.com/post/159968377478/hva-er-galt-med-sorteringnoen-merknader-til. 
Grue, J. (2017, 2. mai). «... uansett hvor mye vi som samfunn legger til rette for det». Minervanett. Hentet 28. mai 2018 fra https://www.minervanett.no/ uansett-hvor-mye-vi-som-samfunn-legger-til-rette-det/.

Grue, L. (2017, 5. mai). Drømmen om det perfekte mennesket. Morgenbladet. Hentet 16. september 2018 fra https://morgenbladet.no/ideer/2017/05/ drommen-om-det-perfekte-mennesket-0.

Giubilini, A., Minerva, F. (2013). After-birth abortion: why should the baby live? Journal of Medical Ethics, 39: 261-263. https://doi.org/10.1136/medethics2011-100411.

Guthrie, W. K. C. (2016). The Greek Philosophers: From Thales to Aristotle. London, Routledge.

Haddad, F., Bourke, J., Wong, K., Leonard, H. (2018). An investigation of the determinants of quality of life in adolescents and young adults with Down syndrome. PLOS ONE, 13(6): e0197394. https://doi.org/10.1371/ journal.pone.0197394.

Harris, J. (2001). One principle and three fallacies of disability studies. Journal of Medical Ethics, 27: 383-387. http://dx.doi.org/10.1136/jme.27.6.383.

Hauser-Cram, P., Warfield, M. E., Shonkoff, J. P., Krauss, M. W. (2001). Children with disabilities: A longitudinal study of child development and parent wellbeing. Monographs of the Society for Research in Child Development, 66(3): 1-131. http://dx.doi.org/10.1111/1540-5834.00151.

Hofmann, B. (2017). 'You are inferior!' Revisiting the expressivist argument. Bioethics, 31(7): 505-514. https://doi.org/10.1111/bioe.12365.

Hofmann, B., Slagstad, K. (2017, 18. mai). Om Sterri er villig til å bruke 300 mill. på å søke etter fostre med trisomi, burde han også tenke gjennom alternativet. Hentet 16. september fra https://www.aftenposten.no/ meninger/debatt/i/dK2X1/Om-Sterri-er-villig-til-a-bruke-300-mill-pa-asoke-etter-fostre-med-trisomi_-burde-han-ogsa-tenke-gjennomalternativet--Hofmann-og-Slagstad.

Hofmann, B., \& Carson, S. (2018). Filosofiens rolle i det offentlige ordskifte. Etikk $i$ Praksis - Nordic Journal of Applied Ethics. https://doi.org/10.5324/ eip.v12i2.2517.

Kahan, D. (2012, 16. august). Why we are poles apart on climate change. Nature, 488(255). Hentet 28. mai 2018 fra https://www.nature.com/news/why-weare-poles-apart-on-climate-change-1.11166.

Lindqvist, H. (2017, 28. april). - Det er viktig å diskutere substansen i det Braanen Sterri sier. Uniforum. Hentet 28. mai 2018 fra http://www.uniforum.uio.no/ nyheter/2017/04/viktig-a-diskutere-substansen-i-det-braanen-sterri.html.

Lindstad, S. (2017, 15. mai). Bør man abortere et foster med Downs syndrom og prøve på nytt? Minervanett. Hentet 28. mai 2018 fra https://www.minervanett.no/bor-man-abortere-et-foster-meddowns-syndrom-og-prove-pa-nytt/.

Magelssen, M., Materstvedt, L. J. (2013). Å granske hjerter og nyrer: Ultralydens etikk. Nytt Norsk Tidsskrift, 30: 28-40.

Magelssen, M., Solberg, B., Supphellen, M., Haugen, G. (2018). Attitudes to prenatal screening among Norwegian citizens: liberality, ambivalence and sensitivity. BMC Medical Ethics, 19:80. https://doi.org/10.1186/s12910-0180319-9. 
Magelssen, M. (2013). Menneskeverd i klinikk og politikk: bioetikk i lys av kristen tro. Oslo: Lunde.

Magelssen, M. (2017, 23. april). Litt verdighet i verdighetsdebatten, takk! Minervanett. Hentet 28. mai 2018 fra https://www.minervanett.no/littverdighet-verdighetsdebatten-takk/.

Manne, K. (2017). Down Girl: The Logic of Misogyny. Oxford: Oxford University Press.

McBryde, J. (2003, 16. februar) Unspeakable Conversations. New York Times Magazine. Hentet 15. september 2018 fra https://www.nytimes.com/ 2003/02/16/magazine/unspeakable-conversations.html.

McMahan, J., Singer, P. (2017, 3. april) Who Is the Victim in the Anna Stubblefield Case? New York Times. Hentet 26. september 2018 fra https://www.nytimes.com/2017/04/03/opinion/who-is-the-victim-in-theanna-stubblefield-case.html.

McMahan, J. (2002). The Ethics of Killing. Oxford: Oxford University Press.

McMahan, J. (2007). Infanticide. Utilitas, 19(2): 131-159.

https://doi.org/10.1017/S0953820807002440.

Michels, R. (1915). Political Parties: A Sociological Study of the Oligarchical Tendencies of Modern Democracy. Oversatt til engelsk av Eden Paul og Cedar Paul. New York: The Free Press. Originalversjonen på tysk er fra 1911.

Mill, J. S. (2008). On Liberty. I Gray, J. (red.) On Liberty and Other Essays. Oxford: Oxford University Press.

Minerva, F. (2014). New Threats to Academic Freedom. Bioethics, 28(4): 157-162. https://doi.org/10.1111/bioe.12066.

Moen, O.M. (2017, 10. april). Statssekretær Bjørnar Laabak (FrP) blander seg inn i UiO-ansettelse. Hentet 28. mai 2018 fra https://moralistene.no/2017/04/10/statssekretaer-bjornar-laabak-frpblander-seg-inn-i-uio-ansettelse/

Oates, A., Bebbington, A., Bourke, J., Girdler, S., Leonard, H. (2011). Leisure participation for school-aged children with Down syndrome. Disability and Rehabilitation, 33(19-20): 1880-9. https://doi.org/10.3109/09638288. 2011.553701.

Parfit, D. (1984). Reasons and Persons. Oxford: Oxford University Press.

Parfit, D. (2017). Future People, the Non-Identity Problem, and Person-Affecting Principles. Philosophy and Public Affairs, 45(2): 118-157. https://doi.org/ 10.1111/papa.12088.

Roizen, N. J. (2010). Overview of Health Issues among Persons with Down Syndrome. International Review of Research in Mental Retardation, 39. https://doi.org/10.1016/S0074-7750(10)39001-X.

Roll-Hansen, N. (2017). Some Thoughts on Genetics and Politics. The Historical Misrepresentation of Scandinavian Eugenics and Sterilization. I Petermann, H. I., Harper, P. S., Doetz, S. (red.). History of Human Genetics Aspects of Its Development and Global Perspectives (167 - 187). Berlin: Springer.

Saugstad, J. (2017, 20. mai). Dødskysset. Klassekampen.

Savulescu, J. (1999). Sex selection - the case for. Medical Journal of Australia, 171: $373-375$. 
Savulescu, J. (2001). Procreative beneficence: why we should select the best children. Bioethics, 15(5-6): 413-26. https://doi.org/10.1111/1467-8519. 00251.

Savulescu, J., Sandberg, A., Kahane, G (2011). 'Enhancement and Well-being'. I Savulescu, J., ter Meulen, R., Kahane, K. (red.) Enhancing Human Capacities (3-18). Oxford: Wiley-Blackwell.

Sidgwick, H. (1981). The Methods of Ethics. 7. utgave (Hackett Classics). Indianopolis: Hackett Publishing Company.

Singer, P. (1979). Practical Ethics. 1. utgave. Cambridge: Cambridge University Press.

Singer, P. (2009). Speciesism and Moral Status. Metaphilosophy, 40(3-4): 568-581. https://doi.org/10.1111/j.1467-9973.2009.01608.x.

Skotko, B. G., Levine, S. P., Goldstein, R. (2011). Self-perceptions from people with Down syndrome. American Journal of Medical Genetics, 155A(10): 2360-9. https://doi.org/10.1002/ajmg.a.34235.

Slagstad, K., Hofmann, B. (2017, 2. juni). Det ligger i blodet. Morgenbladet. Hentet 18. september fra https://morgenbladet.no/2017/06/det-ligger-i-blodet.

Solberg, B. (2008). Frykten for et samfunn uten Downs syndrom. Etikk I Praksis Nordic Journal of Applied Ethics, 2(1), 33-52. https://doi.org/10.5324/ eip.v2i1.1688

Sollien, T. (2017a, 7. april). Gradering av retten til liv. Minervanett. Hentet 28. mai 2018 fra https://www.minervanett.no/gradering-av-retten-til-liv/.

Sollien, T. (2017b, 6. april). - Downs syndrom er ikke en sykdom. Minervanett. Hentet 16. september 2018 fra https://www.minervanett.no/downssyndrom-er-ikke-en-sykdom/.

Sunstein, C. (2012, 17. september). Breaking Up the Echo. New York Times. Hentet 28. mai 2018 fra https://www.nytimes.com/2012/09/18/opinion/balancednews-reports-may-only-inflame.html.

Sterri, A. B. (2014, 9. oktober). Et forsvar for sorteringssamfunnet. Morgenbladet. Hentet 28. mai 2018 fra https://morgenbladet.no/ideer/2014/ et_forsvar_for_sorteringssamfunnet

Sterri, A. B. (2016, 2. april). Hvor bør abortgrensa gå? Dagbladet. Hentet 15. september fra https://moralistene.no/2017/04/02/hvor-bor-abortgrensa$\mathrm{ga} /$.

Sterri, A. B. (2017a, 12. mai). [Bidrag i] Hva er et menneske verdt? Morgenbladet, 8-11.

Sterri, A. B. (2017b, 17. april). Kvinner har god grunn til å ta abort ved påvist Downs syndrom. Minervanett. Hentet 28. mai 2018 fra https://www.minervanett.no/kvinner-har-god-grunn-til-ta-abort-vedpavist-downs-syndrom/.

Sterri, A. B. (2017c, 5. april). Lever personer med Downs syndrom fullverdige liv? Hentet 28. mai 2018 fra https://moralistene.no/2017/04/05/lever-personermed-downs-syndrom-fullverdige-liv/.

Sterri, A. B. (2017d). Sorteringssamfunnet og offentlig filosofi. Etikk og Praksis 10års jubileum, 13. november 2017. Kan oversendes på epost ved henvendelse.

Sterri, A. B. (2018, 1. september). Bør vi tillate abort når barnet er levedyktig? Dagbladet. Hentet 15. september fra https://www.dagbladet.no/kultur/borvi-tillate-abort-nar-barnet-er-levedyktig/70159469. 
Stortinget (2018). Innst. 273 S (2017-2018), innstilling fra helse- og omsorgskomiteen om Evaluering av bioteknologiloven. Hentet 28. mai 2018 fra https://www.stortinget.no/no/Saker-og-publikasjoner/Publikasjoner/ Innstillinger/Stortinget/2017-2018/inns-201718-273s/?all=true\#m5

Sundby, J., Løkeland, M., Schultz, M. (2018, 6. september). Hva med kvinnens menneskeverd? Aftenposten. Hentet 15. september fra https://www.aftenposten.no/meninger/debatt/i/J15QEP/Abortdebatten-Hva-med-kvinnens-menneskeverd--Sundby_-Lokeland-og-Schultz.

Sørvig, Ø. (2017, 2. april). - Jeg var abortmotstander i ett år. Minervanett. Hentet 28. mai 2018 fra https://www.minervanett.no/jeg-var-abortmotstander-ett$\operatorname{ar} /$.

Thomas, K., Girdler, S., Bourke, J., Deshpande, A., Bathgate, K., Fehr, S., Leonard, H. (2010) Overview of Health Issues in School-aged Children with Down Syndrome. International Review of Research in Mental Retardation, 39. https://doi.org/10.1016/S0074-7750(10)39003-3.

Thomson, J. J. (1971). A defense of Abortion. Philosophy \& Public Affairs, 1(1): 4766.

Tonstad, P. S. (2012). Bør være tillatt å oppfordre til terror. UniverS 1. Hentet 17. september fra https://forskning.no/demokrati-juridiske-fag-kriminalitetterrorisme/2012/03/bor-vaere-tillatt-oppfordre-til-terror.

VG (2012, 28. mars). - Helt greit å oppfordre til terror. VG. Hentet 17. september fra https://www.vg.no/nyheter/innenriks/i/3r1gM/helt-greit-aa-oppfordretil-terror.

Wolfers, J. (2015, 23. januar). How Economists Came to Dominate the Conversation. New York Times. Hentet 28. mai 2018 fra https://www.nytimes.com/2015/01/24/upshot/how-economists-came-todominate-the-conversation.html.

Xanthopoulos, M.S., Walega, R., Xiao, R., Prasad, D., Pipan, M. M., Zemel, B. S. ... Kelly, A. (2017). Caregiver-Reported Quality of Life in Youth with Down Syndrome. The Journal of Pediatrics, 10(1): 189(C):98-104.e1. https://doi.org/10.1016/j.jpeds.2017.06.073. 